\title{
Ugalde, Begoña \& Gema Polanco. La fiesta vacía. Barcelona, TEGE, 2019. 137 páginas. ISBN 978-84-09-11313-2
}

\section{Karem Pinto Carvacho ${ }^{1}$}

La trayectoria escritural de Begoña Ugalde se ha manifestado profusa, transitando por los diversos terrenos de la poesía, la narrativa y los textos dramáticos. Oficialmente su voz autorial viene construyéndose desde el año 2011, dando lugar a una estética definida en la introspección, el susurro de lo personal y lo cotidiano, y un discurso que se renueva constantemente manteniendo sus pactos con los relatos de la memoria, la identidad de género y las distintas formas de crítica y sobrevivencia para sortear un mundo adverso.

Leer sus textos significa adentrarse en el espacio que dibuja una escritura fuerte y delicada a la vez, temblorosa y decida, que avanza y retrocede para volver a avanzar. La mayor parte de sus textos poéticos tienen eso de mirar a la infancia, a la juventud y la vida adulta e indagar en sus complejidades (La virgen de las Antenas, Cuneta, 2011; Lunares, Pez Espiral, 2016; y Poemas sobre mi normalidad, Ril Editores, 2018), sobre todo con una perspectiva que tiende a la alianza de los colectivos sociales y a la posición de género, en la que la mirada de mujer focaliza las dificultades y proyecta las ganancias de una experiencia problemática en un sistema donde gobiernan, donde no han dejado de gobernar, los signos del Padre ${ }^{2}$. En este sentido, los textos de Ugalde responden a la larga tradición escritural chilena y latinoamericana de mujeres que desde Agustini, Mistral y Storni, pasando por las poetas de los ochenta, Hernández, Bellessi y Peri Rossi, entre otras, hasta las generaciones

Académica de la Universidad Autónoma de Chile, karem.pinto@uautonoma.cl. Esta reseña se enmarca dentro del proyecto de investigación Fondecyt 1180331. Representaciones de la memoria transgeneracional en producciones artístico-culturales de hijos y nietos en países del Cono Sur, 1990-2017; y del proyecto DIUA 158- 2019, Poesía y Memoria las Imágenes del pasado en la producción escritural de las últimas generaciones en Chile (2003-2018), en conjunto con el trabajo desarrollado al interior del Grupo de investigación Literatura y escuela de la Universidad Autónoma de Chile.

2 Ver Karem Pinto Carvacho. "Una poética de las alianzas. Tensiones, cruces y redes en la poesía de Begoña Ugalde". Revista de Humanidades, Departamento de Humanidades, Facultad de Educación y Ciencias Sociales, Universidad Andrés Bello (Aceptado, 2020). 
actuales, Montero, Dünkler, Smith, etc. -, vienen deconstruyendo el monólogo masculino del escenario literario global.

La fiesta vacía (2019), su último texto poético, nos convoca en esta celebración a la que asistimos solícitas, porque la escritura interesada en la renovación permanente de una oposición activa y organizada debe ser siempre celebrada. Editado por Teje en Barcelona, y elaborado en conjunto con Gema Polanco, quien ofrece 19 fotografías a la obra, este texto se despliega como el encuentro que ambas autoras echan a andar desde campos distintos y cercanos, y que dejan abierto permitiéndonos, como dice Gadamer (1993), participar de este diálogo interminable que es la poesía, la que canta la totalidad de la condición humana. Y que en esta oportunidad se levanta a doble voz para manifestar una terminante posición de desencuentro respecto del Orden actual.

En ese entramado La fiesta vacía se emplaza como un texto que aborda el vértigo del mundo contemporáneo, su cauce frenético y peligroso, sus ruidos blancos y ensordecedores: la ferocidad del neocapitalismo, y que inscribe en medio de "la parafernalia excesiva de la fiesta" (20), el trayecto de una sujeto que, resintiendo el espectáculo del sin sentido, la desigualdad y el maltrato, busca construir "otro hábitat" (33). En esta dirección pienso que La fiesta vacía de Ugalde, sostiene el hilo discursivo identitario y crítico que vienen ensayando sus textos anteriores; sin embargo, la particularidad de este texto radica en el tono ascendente con el que la sujeto lanza su trayecto, en el que se perfila con ánimo decidido y arrojado, pero que además, se reconoce en el trazado de una identidad latinoamericana en ciernes que va al encuentro fortalecedor, como dice Mistral, de sus "raíces alimañas" (Poema de Chile, 672). Así enuncia la sujeto de La fiesta vacía, desde un espacio que reconoce ajeno:

En estas coordenadas imprecisas, perdí las llaves de lo que alguna vez fue mi casa el sentido del humor y casi del olfato pero no olvidé mis coreografías andinas estrategias de guerra florida (42).

En ese movimiento la escritura de Ugalde se da la mano con las discusiones actuales del feminismo latinoamericano, que en el feminismo decolonial y las voces de Yuderkys Espinoza (2009), María Lugones (2010) y Ochy Curiel (2014), entre otras, se resisten a la complicidad de los intereses neocoloniales de producción material y simbólica, tendientes 
a la explotación y el dominio subalternos, y que reconocen una deuda profunda con las presencias y experiencias de las mujeres indígenas y afrodescendientes. Un feminismo que se declara abiertamente anticlasista, anticapitalista y antiracial.

De esta forma, el texto visual que abre a doble página el macrotexto, la primera de las fotografías de Polanco (2-3), resulta fundamental, porque a través del primer plano del cuerpo de una mujer, que sostiene entre sus manos un enorme huevo que cubre todo su vientre, nos declara la diferencia insoslayable de la experiencia femenina, que simbólicamente, además, anuncia un mundo que está a punto de nacer. Desde allí cobra sentido la ruta que la sujeto emprende por las distintas formas en las que la realidad naturaliza su violencia, y que justifican a todas luces la dirección de su proyecto; porque como señalara Benjamin, "No hay documento de cultura que no sea a la vez un documento de barbarie" (Tesis VII, 23). Dice el texto poético:

La fiesta es acaso el estruendo que esconde otro estruendo invasiones a reinos invisibles que no aparecen en los medios de comunicación (74)

En esa ruta viva y dolorosa, la enunciante se transforma, se envejece y por fin establece sus alianzas certeras: "Por eso escribo/nosotras/ yo/ tú/ nosotras" (95), desde allí en adelante la individualidad de su voz se fundirá en la enunciación colectiva para dar paso a la potencia de una comuna de sujetas deseantes y subversivas, adivinas del caos, vivas y acechantes, que traman la emboscada final y se lanzan estrepitosas a la destrucción del Orden dominante y la fundación del proyecto negado, en el que la filiación indígena latinoamericana, esta vez, no será olvidada. Entonces: "nace un sonido inverso/ canto de aves extintas/ rumor de plumaje sagrado" (131).

Fisión, relámpago y creación son las energías que se liberan en las últimas imágenes de la obra y que hacen de este uno de esos textos de finales memorables, de esos libros que cuando terminan de leerse nos contagian de su arrojo, nos imantan los sentidos de la revuelta que quedan flotando en el aire, y que, en el extendido desencanto que hoy nos consume, nos hace recobrar el aliento para sostener una vez más el ánimo de resistencia... y eso, en estos días, resulta ser más que nunca un gesto profundamente necesario. 


\section{Referencias bibliográficas}

Benjamin, Walter. Tesis sobre la historia y otros fragmentos. Edición y traducción Bolívar Echeverría: https://www.bolivare.unam. $\mathrm{mx} /$ traducciones/Benjamin,\%20Tesis\%20sobre\%20la\%20 historia.pdf

Curiel, Ochy. "Construyendo metodologías feministas desde el feminismo decolonial". En Irantzu Mendia Azkue et al. Otras formas de (re)conocer. Reflexiones, herramientas y aplicaciones desde la investigación feminista. 2014, pp. 45-60, glefas.org/ construyendo-metodologias-feministas-desde-el-feminismodecolonial/

Espinoza, Yuderkys. "Etnocentrismo y colonialidad en los feminismos latinoamericanos: Complicidades y consolidación de las hegemonías feministas en el espacio transnacional Feminismo latinoamericano", Revista Venezolana de Estudios de la Mujer, Vol. 14, No 33, julio-diciembre, 2009, glefas.org/etnocentrismoy-colonialidad-en-los-feminismos-latinoamericanos/

Gadamer, Hans George. "El poema y el diálogo. Reflexiones en torno a una selección de textos de Ernst Meister". Poema y Diálogo. Barcelona: Gedisa, 1993.

Lugones, María. "Hacia un feminismo decolonial”. Traducido por Gabriela Castellanos. Hypatia, vol. 25, No. 4, Otoño, 2010, pp. 105-117, glefas.org/hacia-un-feminismo-descolonial/

Mistral, Gabriela. "Poema de Chile”. En Poesías Completas. Santiago de Chile, Ed. Andrés Bello, 2009.

Ugalde, Begoña. La fiesta vacía. Barcelona, Ed. TEGE, 2019. 